\title{
Narrativas de cadáveres e a teleologia da história da World Literature $^{1}$
}

\section{Hector Hoyos ${ }^{2}$}

\section{Tradução: Nelson Shuchmacher Endebo}

Resumo: Este ensaio propõe o cadáver como telos viável para a recente ressurgência da World Literature como paradigma crítico. O argumento é tripartite. Primeiramente, caracteriza dois princípios centrais do paradigma existente: a profissão de um dinamismo fechado em si mesmo e uma ausência implícita de finalidade. Em seguida, apoia-se em Kristeva e exemplos de fiç̧ão latino-americana contemporânea, sobretudo 2666 , de Roberto Bolaño, para apresentar narrativas de cadáveres que acolhem o abjeto e reorientam o exercício crítico à materialidade. Por último, as conclusões propõem uma pauta modesta para um outro "World Literaturismo" que preze por uma materialidade abjeta acima de um idealismo altivo.

Palavras-chave: Necropolítica. Novos materialismos. World Literature. Literatura latinoamericana contemporânea. Cadáveres.

"Eras um deus aos Teucros e às Troianas
Já foste nossa glória, e és um cadáver!"
Homero, Ilíada

In memoriam Ignacio Padilla (1968-2016)

uando se considera o evidente sucesso da World Literature como paradigma crítico desde o seu ressurgimento nas últimas

\footnotetext{
1 "Corpse Narratives and the Teleology of World Literary History" foi publicado originalmente em inglês, na revista Journal of World Literature 2 (2017): 63-79. Aparece pela primeira vez em português aqui, no Cadernos de Letras, em tradução de Nelson Shuchmacher Endebo.

2 Hector Hoyos é Professor Associado e diretor da área de culturas ibéricas e latino-americanas na Division of Literatures, Cultures, and Languages da Universidade de Stanford, sendo também diretor da área de Pensamento e Literaturas Modernas da mesma instituição.
} 
três décadas, é surpreendente quão raramente ela se pronuncia de maneira explícita a respeito de seu porvir. Embora ninguém saiba exatamente o rumo futuro das tendências do presente, elas nos permitem imaginar o amanhã. É de se admirar, em relação ao discurso crítico ao redor da World Literature, que ele venha sendo tão gerativo a despeito — ou seria em razão de? - suas modestíssimas projeções. Hoje, o telos da World Literature é definido por seu próprio dinamismo, e não por um objetivo específico, por vago e amplo que seja. Na melhor das hipóteses, tal dinamismo celebra a convergência das energias criativas dos estudiosos; na pior das hipóteses, incentiva ações sem fins externos, que servem apenas para manter os estudiosos ocupados. Eu abordarei aqui o problema da projeção mediante um fenômeno relativo: a abjeção. Para tanto, eu me apoiarei em uma constelação de referentes teóricos e exemplos literários, enfatizando, porém não me restringindo, a ficção latino-americana contemporânea. Minha meta é propor o cadáver como um telos viável para a World Literature.

Procederei ao longo de três seções. Na primeira, especularei a respeito do telos implícito do movimento a fim de situar minhas ideias. $\mathrm{Na}$ sequência, apresentarei narrativas de cadáveres que acolhem o abjeto e apontam o exercício crítico na direção da materialidade. Por último, esboçarei conclusões gerais e uma modesta proposta de pauta para um outro "World Literaturismo". Nesse neologismo, propositalmente cacofônico, adoto o sufixo -ismo para reiterar que vejo esta abordagem como uma entre outras, e não como uma metateoria. Na mesma toada, enfatizo as maiúsculas em World Literature em referência ao aspecto mais institucionalizado, mainstream, do fenômeno, representado pelo periódico Journal of World Literature e seu congênere Institute for World Literature (do qual, esclareço, sou colaborador). Creio também ser útil desfamiliarizar termos cognatos da Weltiteratur, havendo, de outro modo, sempre o risco de empregá-los de modo acrítico. Por isso, ocasionalmente utilizarei também outro termo que tenho visto circular, weltlit, mais coloquial, nos 
moldes de complit, mais conhecido. A meta crucial do meu argumento é dar uma contribuição para a World Literature que, por um lado, reconhece uma afinidade pelo paradigma emergente, e, por outro, questiona aspectos de sua evolução e, por fim, sugere os primeiros passos para que se melhor defina um senso de finalidade para o movimento.

\section{A finalidade sem um fim gera mal-estar}

Nem todos veem problema em conceber a crítica worldlit como puramente autotélica; decerto, a intensificação do diálogo entre críticos que outrora não conversavam é bem-vinda. Menos evidentes, todavia, são os motivos pelos quais tais conversas devam ocorrer precisamente em torno do termo World Literature, e não de outra categoria abrangente. Seguramente, a terminologia pode ser fator secundário caso o diálogo em si seja produtivo. Em uma abordagem nominalista, poder-se-ia substituir World Literature por qualquer outro lema que fomente discussão, assim como aconteceu com Differánce, quando esse termo se encontrava em voga. Entretanto, a tendência crítica que viemos a conhecer como "desconstrução" tinha ideias um tanto concretas sobre aquilo que buscava alcançar: desmistificar binarismos.3 De fato, há em trabalhos de referência tão esclarecedores como The Routledge Concise History of World Literature (2012), de Theo D’Haen, uma sintomática ausência de objetivos - isso para não falar de teoria. $\mathrm{O}$ volume cumpre com louvor a tarefa de contar a "história" da World Literature desde o influente aforisma de Goethe sobre Weltiteratur, passando por Curtius e Auerbach, até chegar em Moretti, Casanova e os debates atuais. O livro também explora pedagogia, tradução e tópicos não europeus. Esse expansivo relato do passado e do presente da

3 Na formulação sucinta de Derrida (1991, p. 372), menos uma definição que uma ilustração: “A desconstrução não consiste em passar de um conceito para outro, mas em modificar e em deslocar uma ordem conceitual assim como a ordem não conceitual à qual se articula”. 
World Literature carece, porém, tanto de uma seção dedicada a imaginar o futuro do paradigma como de uma conclusão. (Cada capítulo termina com uma lista de conclusões principais resumidas, uma súmula para estudantes). Em tão conspícua ausência, detecto um gesto de afirmação do bem intrínseco do worldliteraturismo.

Thomsen evidencia esse último ponto ainda mais pronunciadamente em Mapping World Literature (2008), onde ele observa que "o aspecto saliente sobre o futuro da World Literature é a maneira como o rótulo vem sendo aplicado para efetivar mudanças institucionais numa época em que campos de pesquisa estão sendo redefinidos, e currículos determinados, em certa medida, pela ideia do que deverá ser relevante no futuro" (THOMSEN, 2008, p. 30-1). Note a circularidade desse raciocínio, que podemos bem descrever como um reformismo autorreferente: World Literature merece ser ensinada pois há valor em estudá-la. Nesse raciocínio, não há espaço para a importância da literatura fora das instituições; tampouco para o referencial na literatura, isto é, como ela se conecta com o mundo. Em trabalhos posteriores, como veremos a seguir, Thomsen apresenta maiores nuances; no entanto, essa formulação serve para ilustrar o ponto: tais pronunciamentos ou são tautológicos - leia-se: ideológicos - ou, prefiro eu crer, marcas dum ato de fé.

No primeiro caso, confrontamo-nos com aquilo que Žižek (1996, p. 142) chamaria de um "objeto sublime da ideologia", isto é, um daqueles "significantes sem significados" constituintes das comunidades políticas identificadas "com o próprio gesto de se identificar". Essa avaliação não aparenta ser de todo errada, mas, em última análise, se a World Literature for mesmo isso, ela nos parece um objeto sublime da ideologia dos mais benignos: as piores consequências ideológicas imagináveis derivadas disso estão bem longe dos cenários calamitosos que podem decorrer, por exemplo, da manipulação de elementos discursivos como o termo "segurança". Além disso, como bem nota Damrosch, "relações literárias 
interculturais" precedem em muitos séculos as nações modernas e as instituições literárias, como comprovam as trocas comerciais ao longo da Rota da Seda e do Oceano Índico (DAMROSCH, 2014, p. 3). Observações de fatos dessa natureza poderiam dissipar o temor de que, em última análise, "não há aí aî" [there is no there there]: a circulação é algo para o qual podemos apontar e chamar de World Literature. Isso nos faz perguntar se o papel do crítico não seria suprir relatos sobre a circulação de tradições orais e textuais, sejam elas do passado ou do presente. Ora, como o foco sobre a circulação produz mais circulação, é como se se cumprisse uma profecia autocumprida. Em outras palavras, as discussões sobre finalidade são substituídas pela axiologia autotélica e por exibições virtuosísticas de erudição.

A hipótese do ato de fé tampouco é livre de problemas. Esvaziada de conteúdo, a projeção ancorada em autoafirmação e expansão institucional é excludente por decreto. Ainda exibindo um ethos notavelmente inclusivo (e salutar), há o risco de que ela exclua via inclusão, mutatis mutandis, ao modo da Igreja Católica. Dado o histórico luterano de Goethe, bem como suas simpatias politeístas, há certa ironia no fato de que a "igreja invisível” de tutores da World Literature, que ele previra nos anos 1830, se pareça muito mais com a Igreja de Roma. ${ }^{4} \mathrm{~A}$ World Literature abre as portas para todas as literaturas, e assim se imiscui da questão, mais pedregosa, de abrirse para visões incompatíveis ao definir literatura. Poder-se-ia argumentar que tais diferenças podem ser resolvidas ao longo do caminho; basta, primeiro, "sentar-nos juntos à mesa". Donde o contra-argumento: mas por qual razão essa mesa? A canonização, noção teológica tão secularizada quanto as estruturas estatais que Carl Schmitt tinha em mente, é cada vez mais um caso de complexio oppositorum. Isso, decerto, rende a certas instituições privilegiadas um papel seletivo descomedido, que troca

4 A respeito da "igreja invisível” de Goethe em relação à World Literature, ver Damrosch (2003, p. 17). A respeito das ideias religiosas de Goethe, consultei Walter Naumann. 
linhagens partidárias por pontificantes cutucadas. Nesse processo, o poder que convoca torna-se poder tout court. (Isso talvez explique a razão de o paradigma encontrar mais simpatia entre leitores, genealogias e obras de referência marcadas por opiniões parcialmente convergentes, do que em monografias caracterizadas por uma metodologia consistentemente aplicada). Mais do que reconstituir argumentos conhecidos já levantados contra a World Literature, eu sublinho a estrutura recursiva que leva à absorção de visões opostas no interior do paradigma.

O exemplo mais notável disso é o ponderado e apropriadamente intitulado Against World Literature, de Emily Apter (2013), argumento em prol da recuperação daquilo que se perde no ato tradutório. Trata-se de um exercício tanto de refutação quanto de oposição leal. O contagioso entusiasmo pela World Literature transcende diferenças metodológicas, as mais robustas: Apter frisa a teorização "tradicional", ao passo que outros acentuam o eruditismo ou a análise social. Tais abordagens seriam incompatíveis, ou até mesmo antagônicas, não fosse a larga etiqueta institucional que as encima. Essa fé no dinamismo verifica-se também em Damrosch (2008, p. 483), quando diz que "a verdadeira história da World Literature está no futuro, e não no passado". Gostaríamos de saber: que futuro é esse? As respostas são bem menos prolixas. O projeto se empenha essencialmente em produzir as molduras dos quadros, e não em pintá-los; ou, para usar outra metáfora, em escrever o conjunto mínimo de regras para um jogo que outros jogarão.

Deparamo-nos com espírito semelhante no estatuto de fundação do JWL, Journal of World Literature. Entre as prioridades da publicação, encontramos um desejo de reunir estudiosos, criar um fórum e fomentar discussões "mais amplas e aprofundadas". Como é de se esperar de uma publicação ecumênica, veem-se poucos elementos prescritivos ou axiológicos, à parte de um enfoque para além do nacional e uma abordagem cosmopolita, respectivamente. Fala-se muito no como (redes, 
colaborações) e muito pouco no quê, a não ser que se entenda este último por "tudo". Ora, pauta tão irrestrita não tem como não sofrer com uma versão ainda mais expansiva daquilo que Gerald Graff chamara, em 1986, de "buscar abrigo sob a cobertura em si (take cover in coverage)". Um tratamento tão abrangente dos fatos da literatura em escala global permitiria que os estudiosos deixassem "passar batido", sem exame, "a teoria sobre a qual sua prática se sustenta", nas palavras de Norman Foerster citado por Graff (FOERSTER, apud GRAFF, 1986, p. 41). Em um sentido, a World Literature pode ser infinita; noutro, completamente plana: ilimitada quanto à cobertura, mas absolutamente limitada em termos de teoria e referencialidade. Ademais, "tudo" aqui é uma impossibilidade lógica. $\mathrm{Na}$ falta de um Aleph, o objeto imaginário de Borges, que mostra todos os pontos no universo e todos os pontos de vista ao mesmo tempo, as coisas se dão sucessivamente (HOYOS, 2015 p. 14-69). O elusivo quid da World Literature seria, portanto, um trabalho infinitamente diverso no qual nós, ainda assim, deveríamos nos empenhar imediatamente.

O fundamento dessa empreitada "hipergerativa" e paradoxal já se fazia presente na citadíssima formulação de Goethe: “a época da WeltLiteratur é iminente, e todos devemos empenhar-nos em apressar a sua chegada" (GOETHE apud DAMROSCH, 2003, p. 19-20). Compare: "Rápido! Godot vem vindo, temos que arrumar a casa!". "Iminente" traduz an der Zeit; "apressar", beschleunigen. Ambas as palavras inequivocamente evocam velocidade. Essa passagem, tantas vezes mencionada, permanece opaca. Se a época é iminente, por que apressar sua chegada? "Todos devemos empenhar-nos em apressar a sua chegada" dá a impressão de uma convocação de uma massa crítica como "autovalidação": decerto, se quase todos se empenhassem, a época, em certo sentido, já teria chegado. Porém, se tal patamar não for atingido, quem perde é o dinamismo. Hospitalidade implica risco, incluindo aí a possibilidade de os convidados não comparecerem - nesse caso, de eles não compartilharem a expectativa 
da nova época. O ponto fraco do poder convocador é requerer a presença dos convocados; o ponto forte é que ninguém deseja ficar sem convite. Todos devemos. As palavras de Goethe insuflam entusiasmo (begeistert), inaugurando uma temática capaz de atravessar as décadas até chegar ao $J W L$. Isso coincide com aquilo que Pheng Cheah, em uma intervenção motivada por razões semelhantes às deste artigo, acertadamente chamou de espiritualismo: a tendência de achar que intercâmbios literários constituem uma ordem espiritual superior (CHEAH, 2016, p. 6). O “autotelismo" alça voo.

Não podemos esperar que as memórias de Eckermann sobre suas conversas com Goethe, tampouco as parcas menções ao termo pelo próprio poeta, sirvam de oráculo para o estudo da literatura hoje. Sem dúvida, montar o quebra-cabeça do que Goethe possa ter intencionado e decidir o que queremos fazer com isso tudo são empreitadas fascinantes. Igualmente fascinantes deveriam ser, entretanto, os debates sobre o classicismo esteticista de Goethe, uma fuga da política que Adorno entendera como acordo e Benjamin como capitulação (HOHENDAHL, 2011). (De fato, algumas linhas mais tarde, Goethe evoca os gregos como representação a-histórica da beleza da humanidade - nenhuma pressa nesse ponto!). Para os propósitos desse artigo, basta notar, com base em outro pensador alemão que, ao tratarmos de Weltliteratur, parecemos estar lidando com a Beleza. "Beleza", escreve Kant, "é a forma da finalidade de um objeto, na medida em que é percebida nele sem a representação de um fim" (KANT, 2016, p. 132, \$17, 236). Zweckmässigkeit ohne Zweck é uma descrição apta do entusiasmo que é a World Literature. Um pôr-do-sol e um poema não precisam existir do mesmo modo que um martelo. Como o martelo, eles parecem ter um propósito, mas nenhum em particular. Assim ocorre, vimos aqui, com a World Literature. Assim como a Beleza, é de bom tom tomá-la cum granum salis. 


\section{Cadáveres heróis}

O medo da morte é uma das forças motrizes por trás da ressurgência da World Literature, um paradigma praguejado por uma ansiedade do tipo ars-longa-vita-brevis ou, como quer Damrosch, pegando emprestadas as palavras do poeta metafísico Andrew Marvell (2003, p. 112), pelos apuros de não se ter "mundo o bastante, nem tempo". Dado a vida ser curta demais para lermos um cânone expandido de livros pinçados de várias culturas, pelo menos podemos abordá-los de modo mais ou menos superficial. Que tal, porém, se em vez de fugirmos diante da morte, nós a encarássemos? Nós nunca vemos a "morte"; o conceito em si já é abstrato, espiritualista. Portanto, a jogada materialista mais radical consiste em voltar nossa atenção ao cadáver, objetivo da segunda parte desse ensaio. "Uma ferida com sangue e pus, ou o odor adocicado e acre de um suor, de uma putrefação, não significa morte”, escreve Kristeva (2011, p. 3), “...sem disfarce e sem máscara, tanto o dejeto como o cadáver me indicam aquilo que eu descarto permanentemente para viver". Aqui reapresento uma noção familiar aos estudantes de literatura pré-worldlit: o abjeto, aquilo que se rejeita. A psicanálise lacaniana o posiciona na base da subjetividade, definida em oposição àquilo que rejeita.5 "A cada eu seu objeto, a cada supereu seu abjeto", observa Kristeva (2011) algumas linhas antes. Uma World Literature aspiracional, espiritualista, ao fundir o real e o representado, inflige sobre si mesma a violência de deserdar seus próprios refugos. Numa imagem: o crítico ideal, superegóico e imorredouro, contempla os monumentos da cultura, esquecendo-se da carne putrefata a que o mármore, em certo sentido, sobrevive. O cadáver nos ensina a negociar a tensão entre literatura e mundo.

5 Mariano Siskind (2014) já argumentou, apoiando-se em Lacan e outros referentes psicanalíticos, que o desejo pela mundanidade [worldliness] constitui uma força motriz para escritores latino-americanos. O corporal não tem lugar central em seu argumento. 
Eu sigo as pistas do escritor chileno Roberto Bolaño (1953-2003). Considere a seguinte parábola, uma trama secundária em Nocturno de Chile (2000), um romance sobre um crítico literário moribundo. Um sapateiro da corte vienense, motivado tanto por um zelo patriótico quanto por um desejo de melhorar seu status social, torra toda a sua modesta fortuna na construção de um parque de esculturas e cemitério para os heróis do império austro-húngaro. Ele encontra um terreno perfeito para tal empreitada, e a ele dá o nome de Heldenberg, a Colina dos Heróis. A piada se dá aos custos do próprio sapateiro: ele acaba sendo enterrado ali, antes da conflagração da Primeira Guerra Mundial e, portanto, morre sem saber que dali para frente não haveria mais heróis nem no império austrohúngaro, nem em império algum. Mais tarde, quando tanques soviéticos - note a elipse - por ali passam, eles dão de cara com sua cripta, quase um cofre, no topo da colina desolada; e dentro dela, seu cadáver, "as órbitas vazias [...] e a queixada aberta como se, depois de entrever a imortalidade, ainda estivesse rindo" (BOLAÑO, 2000, p. 46). Ora, a piada se dá ao nosso próprio custo, leitores empenhados em venturas igualmente fúteis, igualmente inconscientes das contingências históricas e, a despeito disso, igualmente destinados a morrer. O étimo de cadáver, em espanhol, é o latim para "cair". Esse cadáver alçado ao topo da colina realça o colapso do alto e do baixo, a inevitável abjeção que há na projeção, a carnalidade putrefata de futuros imaginados.

Bolaño, cuja obra não poupa os críticos e idolatra leitores não profissionais, zomba da mesquinharia da busca pela grandeza e da subserviência à volátil política que alegadamente subjaz a história da literatura. (Ele exagera). O chileno autoriza, quiçá cultiva, uma leitura vitalista ingênua, quase anti-intelectualista, de sua obra. Seguindo essa linha, diante da charada da ars longa, vita brevis, a sugestão de Bolaño é que se viva mais e se leia menos. Esse, porém, é um curto momento de uma operação mais complexa. Em outro plano, Bolaño invoca os poderes 
do horror, termo usado por Kristeva para imbuir a história literária global de uma renovada atenção à materialidade. Os intercâmbios literários e culturais dados nos diversos lugares que povoam seus livros, finos ou grossos, são centrados em corpos, e não só ideias, itinerantes. De fato, é possível compreender toda a obra de Bolaño como permutações de três elementos: sexo, literatura e viagem. ${ }^{6}$ Uma breve ilustração: considere o ensandecido poeta que perambula pelo sudeste norte-americano em $\mathrm{La}$ literatura nazi en América (BOLAÑO, 1996). Ele imagina um centenário Ernst Jünger e uma nonagenária Leni Riefenstahl, praticamente cadáveres, transando furiosamente: "ossos e tecido podre chocando-se e roçando um no outro" (BOLAÑO, 2008a, p. 145). Trata-se de uma imagem lancinante, um tanto agravada pelas proclividades fascistas da personagem lembretes, como as finíssimas botas do sapateiro vienense, da heteronomia da literatura. O ponto aqui é que a World Literature não pode ser a respeito de almas puras.

Em nenhum outro lugar na obra de Bolaño isso é mais visível do que no conto "El retorno", em Putas Asesinas (2001). Assim como Memórias Póstumas de Brás Cubas, do mestre brasileiro Machado de Assis (1991), a narrativa é um relato em primeira pessoa feito por um defunto. É, além disso, uma história de necrofilia, e, acredite, uma história de amor: um sujeito festeiro, cujo nome não conhecemos, sofre uma parada cardíaca na pista de dança; seu fantasma testemunha seu corpo ser contrabandeado do necrotério para uma mansão em Paris. Ali, Jean-Claude Villeneuve, um célebre estilista, faz sexo com o corpo morto. $O$ fantasma o confronta, o estilista pede perdão, e o perdão é concedido. Ao fim do conto, os contrabandistas voltam para buscar o cadáver. O narrador fantasma decide permanecer na mansão, onde se torna confidente do solitário necrófilo, que passa a maior parte do seu tempo falando consigo mesmo, sem

\footnotetext{
6 "Kafka comprendía que los viajes, el sexo y los libros son caminos que no llevan a ninguna parte, y que sin embargo son caminos por los que hay que internarse y perderse" (BOLAÑO, 2003, p. 158).
} 
parar. O modo como o conto desloca simultaneamente gênero literário e gênero sexual lembra "La Loi du genre", de Derrida7. Gênero literário pois efetivamente obscurece as fronteiras entre conto fantasmagórico (como o fez Machado) e relato realista, sem firulas. Gênero sexual, pois, usa uma confissão de saída do armário (coming out), que a psiquiatria ocidental por muito tempo considerou perversão, para modelar uma espécie de entradano-armário (coming in) perversa: um homem hétero vira gay, um necrófilo se torna parceiro doméstico. Enquanto Villeneuve toca as genitais do morto, o fantasma pensa em Cécile Lamballe, "a mulher de seus sonhos", que o abandonara morto na pista de dança.

Entre os muitos aspectos dignos de nota nessa história de abjeção, o uso da linguagem é o que mais nos interessa. Na tradição lacaniana, cadáveres e excreções corporais sempre fazem intermédio entre mundo e linguagem e, portanto, literatura. Esse é o caso aqui, em um metanível. Os leitores não se confrontam com o real (a não ser que façam a leitura numa sessão espírita dentro do necrotério), mas leem a seu respeito. Ainda assim, o conto transmite em algum grau o caso-limite que o cadáver representa em termos de linguagem. A significação sofre perdas. O protagonista medita: "meu corpo ou meu ex-corpo (não sei como me expressar a seu respeito)" (BOLAÑO, 2008b, p. 122); profere o enunciado impossível "meu cadáver"; fala sobre os próprios restos mortais em primeira pessoa, com um certo humor obscuro ("não tive estômago para ver como abriam meu corpo”), para logo em seguida retomar a terceira pessoa. Isso tudo parece verossímil, pois "ele" ainda se está acostumando a estar morto; assim como é plausível que, dentro da economia do conto, o protagonista perdoe e faça amizade com Villeneuve, em virtude de "seu" corpo já não ser mais seu e, no fim das contas, um fantasma não é nem ele, nem ela. Essa presunção,

7 "La loi du genre" é o título de uma comunicação apresentada por J. Derrida em julho de 1979, por ocasião de um colóquio internacional sobre gênero, organizado em Estrasburgo pelas universidades de Estrasburgo e a Johns Hopkins, de Baltimore. 
no sentido técnico do termo, confronta-nos com a arbitrariedade do significante, não só dos pronomes pessoais e possessivos, como também da própria noção de "cadáver". Como bem coloca Natalie Depraz no Dictionary of Untranslatables, a tríade em alemão Leib/Körper/Fleisch só pode ser vertida para o espanhol como carne/cuerpo ou o questionável lived-body/body/flesh em inglês (DEPRAZ, 2014, p. 561). Para elucidar o ponto, basta pedir para alguém tirar "o corpo do frango da geladeira”. Uma frase um tanto assustadora, mas talvez consumidores mais conscientes saibam apreciar. No entanto, uma frase também hilariante, como numa crise nervosa de risos: nós somos o que comemos.

O relato multiplica as fortes conotações da palavra "cadáver", e ao mesmo tempo lança mão de engenhosos trocadilhos. Leia "El retorno" como "el re-torno", uma reescritura da cena da roda de oleiro do drama hollywoodiano Ghost, dos anos 1980, que o protagonista menciona en passant. Ou leia "Cécile Lamballe" como ceci l'emballe, "isso cobre ou embala", o que se torna ainda mais pleno de sentido à luz da profissão de Villeneuve, o "embalador de corpos", nome que se poderia dar a um estilista. Emballer também é usado coloquialmente para indicar os atos de seduzir, excitar e, até mesmo, fazer alguém embarcar em uma viatura policial - todas essas alternativas permitem outras leituras do conto, tenha sido ou não essa a intenção de Bolaño. Outras pistas podem ser encontradas quando o narrador relata como Villeneuve contempla (seu) corpo, e presumivelmente tenta "adivinhar que esperanças e desejos palpitaram uma vez naquele vulto envolto num saco de plástico". Ou ainda esta passagem, bastante provocante, no necrotério, antes da mansão:

Em vida, tive medo de ser um joguete (ou menos do que um joguete) nas mãos de Cecile e, agora que estava morto, esse destino, antes origem das minhas insônias e da minha insegurança rastejante, se apresentava doce e até não desprovido de certa elegância e de certo peso: a solidez do real. (BOLAÑO, 
2008b, p.124)

Nesse detalhe sobre o joguete, a passagem fornece uma caracterização do tímido narrador-protagonista, o qual, ao lembrar-se da amante, pensa numa femme fatale. Até onde ele saiba, é bem possível que ela tenha sido mesmo fatal, fato a adicionar mais outra camada - com o perdão do trocadilho - a seu envolvente nome. Os parênteses, contudo, são curiosos: é difícil imaginar algo menos do que o apego infantil a objetos. Uma interpretação possível é que Cécile, a criança imaginada na metáfora, brinca com ele a seu bel-prazer. Outra leitura aponta para um encontro mais elementar entre um ser humano vivo e um objeto inanimado. Não é coincidência que o protagonista sinta falta do toque humano, um tropo comum em histórias de fantasmas, que prenuncia os atos sexuais que se seguirão. Nesse ponto eu vejo Bolaño usar todos os recursos literários à sua disposição para indicar algo além das p,alavras, um quiasma primordial entre língua e mundo. Perceba o telos desse conto, tão relevante para a World Literature como um todo: a direção é a realidade básica e ilibada da matéria.

Todas essas ideias se reúnem no longuíssimo romance inacabado 2666 (2004). Se, como quer Umberto Eco, o medo da morte nos motiva a fazer listas, o que dizer de uma lista de cadáveres? "A parte dos crimes", a seção mais famosa e menos lida - a mais insuportável - do romance, é um aglomerado sem enredo de narrativas de cadáveres. Uma lista, ela proporciona aos leitores a contemplação distante, tal qual um frequentador de museus diante de uma sublime pintura de uma tempestade no oceano. O conteúdo, contudo, é horrendo, e resulta numa comoção sincera. A leitura dessa seção é uma variadíssima sucessão de ultraje moral, culpa por omissão, fascínio mórbido, nojo e anestesia. Em traços gerais, eu gostaria de propor o esqueleto de um argumento (cuja carne - o que há numa metáfora? - publicarei em outra ocasião): a inclusão dessa seção no meio 
do romance ilustra o possível significado da aposta que coloca a busca pela justiça, assunto sem dúvida mais importante que a historiografia da literatura mundial, como o futuro da World Literature.

"A parte dos crimes" é a quarta das cinco seções de 2666, cada uma delas tão longa quanto um romance tradicional. A primeira parte apresenta o enredo geral do romance, o qual gira em torno da busca por Archimboldi, um clássico alemão incógnito, quem, segundo rumores, se encontra no norte do México. A segunda parte põe em segundo plano os críticos que saíram à sua procura e foca no professor de filosofia chileno exilado que lhes dera abrigo, e sua filha, Rosa. A terceira se concentra em um jornalista esportivo afro-americano, o qual acaba ajudando Rosa a sair do México para os Estados Unidos, onde ela presumivelmente estaria a uma distância segura da violência contra a mulher, alimentada pelo narcotráfico, que assola tanto o México ficcional quanto o real. De certo modo, "A parte dos crimes" interrompe as conexões cada vez mais transitivas a Archimboldi: os críticos que o buscam, seus conhecidos, e os conhecidos desses conhecidos. Em vez disso, a seção aborda relatos forenses levemente ficcionais de casos de mulheres que poderiam ser Rosa. Ao mesmo tempo, porém, o texto dá deixas para uma interpretação paranoica, demoníaca (“666”), segundo a qual Archimboldi estaria por trás de todos aqueles crimes. A quinta e última seção desfaz essa impressão, e apresenta um relato da vida do escritor, marcada pela Segunda Guerra Mundial e o pós-guerra. O círculo do enredo principal nunca se fecha, por assim dizer. Ao fim temos Archimboldi, agora um escritor famoso, recluso e caduco, viajando para o México à procura de um sobrinho, homem brutal e violento apresentado na terceira seção, mas que agora surge encarcerado sob alegações espúrias.

Tivesse Bolaño "mundo o bastante, e tempo", talvez ele tivesse produzido um romance mais enxuto com base no texto revisado. (Ele faleceu por complicações decorrentes de uma falência hepática, aos 
cinquenta anos, em 2003). No entanto, essa hipótese não é provável. Outro romance dos mais longos, embora não tão extenso, Los detectives salvajes (1998) é igualmente aberto, e também gira ao redor de uma busca por um autor, no caso, Cesárea Tinajero. Ambos os romances varrem o mundo, levando o leitor a lugares tão distantes quanto Beer Sheva, Colônia, Kostekino, Manágua, entre outros. Localizações africanas e, especialmente, asiáticas são menos representadas, pois a cosmovisão de Bolaño é latinoamericano-cêntrica e, talvez por razões de verossimilhança, porque os intercâmbios literários entre as regiões não são tão comuns. (Grande parte dos eventos em sua ficção acontece no oeste europeu, como ocorre em boa parte da literatura latino-americana: veja $O$ jogo da amarelinha, de Cortázar). O negócio de Bolaño é lançar a isca para o desavisado morder. No fim do romance de 1998, a mãe de toda a poesia vanguardista é finalmente encontrada, mas morre. No romance póstumo, o mestre da literatura do século XX simplesmente se esvai. As histórias confundem os leitores, suas inclinações humanistas residuais (declaradas ou não) e crença no conceito de gênio artístico - categoria morosa que Bolaño sem sombra de dúvidas rejeitaria. Esses dois romances conduzem o leitor, por meio de uma construção cuidadosamente paratática, a um horizonte materialista. O que sobra em Los detectives selvajes, o mais ágil dos dois, é o desejo corporal e suas múltiplas ramificações, exploradas em toda a riqueza de detalhes; o que resta em 2666 é, ora bolas, um monte de restos.

A World Literature lida com fenômenos de larga escala e importância histórica internacional o tempo todo. Seja por conta da difusão da forma do romance por todos os continentes, seja por conta das ressonâncias transculturais da épica, o trabalho de nós estudiosos se sente cada vez mais à vontade entre redes e interconexões complexas. Enquanto isso, seis mulheres são assassinadas diariamente no México, uma estatística em si assustadora que é, a despeito disso, apenas parte de um fenômeno global muito maior: de acordo com a ONU, o México ocupa a sexta posição no ranking de 
feminicídios. ${ }^{8}$ Por que nós, estudiosos de literatura, não deveríamos nos envolver com algo tão significativo, prevalente, rizomático e urgente? Uma resposta blasé seria: pois não somos ativistas, jornalistas, criminologistas ou forenses. Mas tampouco o foi Bolaño, e ele assimila todos esses quatro discursos com fôlego notável, demonstrado tanto na pesquisa de fundo para o romance quanto em sua própria escritura. Sem nunca deixar de ser uma obra literária, independentemente da definição que dela tenhamos, 2666 alarga o limite da forma de modo a tocar aqueles outros domínios. A hermenêutica forense da passagem acima é caso ilustrativo: em um mise en abyme, o médico legista "lê" uma fauna cadavérica em busca de pistas, enquanto os leitores fazem o mesmo.

De maneira sutil, a fim de evitar comparações impossíveis, 2666 desenha um arco que vai do genocídio ao feminicídio. Menções à Shoah são poucas, mas o romance a evoca mediante a barbárie nazista ao redor de Hans Reiter, o nome verdadeiro de Archimboldi. É possível que Bolaño se tenha inspirado na Dialética do Esclarecimento, de Adorno e Horkheimer (2014), e certamente no ímpeto com que os autores questionam toda a civilização ocidental à luz dos horrores de sua época. Após analisarem minuciosamente as justificativas do perpetrador em Sade, eles observam: "A explicação do ódio contra a mulher, enquanto criatura mais fraca em termos de poder físico e espiritual e marcada na testa pelo estigma da dominação, é a mesma do ódio aos judeus". Adorno e Horkheimer viram o antissemitismo como o desenrolar das contradições internas ao pensamento do Esclarecimento, o qual eles buscavam esclarecer. Se a comparação entre Bolaño, Adorno e Horkheimer se sustenta, leituras do romance farão bem em discernir as dinâmicas culturais de larga escala que abrem caminho para o feminicídio. No espaço desse argumento, concluise que o impulso de Bolaño para aproximar o simbólico e o real, apesar de

8 Como notou Arnoldo Kraus no jornal mexicano El Universal (2016). 
ser uma tarefa impossível, o carrega desde uma necrofilia hollywoodiana até um problema social de envergadura. Trata-se de um fenômeno cuja compreensão, para não falar da sua solução, nos excede. Bolaño escreveu o romance global latino-americano mais curto e modesto que era preciso para aproximar a escala e significância mundial desse horror.

O chileno não é o único autor latino-americano pós-1989 a confrontar-se com formas extremas de abjeção. Para se ter uma ideia, pensemos em Los ejércitos, do colombiano Evelio Rosero (2006), retrato musical chocante da violência paramilitar no interior do país, a qual propositalmente envolve cadáveres de um jeito incabível de descrever aqui. $\mathrm{O}$ romance amplia a capacidade do leitor de absorver os horrores da história, no entanto, perder a empatia. Ou o garrido conto "Dieguito", do argentino José Pablo Feinmann, no qual a criança idiota que dá nome ao conto reconstitui, na base da costura, o corpo defunto do ícone do futebol mundial Diego Armando Maradona. Quando o pai da criança a questiona sobre o que anda fazendo, Dieguito responde: "Dieguito Armando Maradona”. Eis aí uma frase de arremate histericamente engraçada, sobretudo para leitores familiarizados com os usos e abusos do gerúndio espanhol, como no português: armando, juntando, montando. A mente faz piruetas quando percebe que a figura abjeta talvez sirva de sinédoque para a Argentina. Já a chilena Diamela Eltit, figura imensamente influente, porém ainda não devidamente traduzida para o inglês, voltou sua escrita para o sofrimento real de diversos modos, resultando em obras experimentais densas, como Impuesto a la carne (2010). O próprio título faz um insinuante jogo de palavras, sugerindo simultaneamente um imposto cobrado sobre o preço da carne, e algo imposto sobre o carnal. El material humano (2009), do guatemalteco Rodrigo Rey Rosa, faz ficção de arquivos da criminologia com o intuito de produzir uma densa colagem da violência presente e passada, enquanto seu compatriota Eduardo Halfón, em seu conto "Han vuelto las aves" (2015), insinua, pela via negativa, a presença do cadáver de 
um líder comunitário assassinado, mantendo o foco da narrativa sobre as frondosas plantas de café no terreiro da família.

A escritora latino-americana honorária Patti Smith, roqueira punk e memorialista, dedicou a Roberto Bolaño seu poema "Hecatomb" (SMITH, 2013), escrito em cem versos sem estrofes. (Ela também homenageou em inúmeras ocasiões o argentino César Aira). Entre os versos relevantes, destaco "a veste do poeta é pele"; "Um poema de morte perpétua / derrotando os gregos / no precinto da musa”. Smith claramente medita sobre cadáveres: das mulheres de Juárez, ficcionalizadas na Santa Teresa de Bolaño ("uma cidade com o formato de um vestido"); do autor chileno cuja reputação espalhou-se como um incêndio florestal após sua morte ("nós, os reveladores / dispensáveis, não-solicitados / trocamos nossas fichas pelo prêmio"). Caso alguém ainda creia que a atenção dada ao cadáver se restrinja à representação de um realismo macabro, o desenhista colombiano José Antonio Suárez, em um belíssimo livreto ilustrado publicado pela SML Ediciones de Medellín, verte de maneira falsamente ingênua uma cena do poema, o sacrifício de cem bois, em iterações vivamente coloridas de anéis de nariz de gado.

Tanto Suárez quanto Smith pinçam algo do manual de jogadas de Roberto Bolaño: em seu cuidadoso preparo, lento e gradual, para as cenas de crime, Bolaño nos ensina uma sensibilidade quanto à carne humana pela via da carne. Na primeira seção de 2666, "A parte sobre os críticos", acadêmicos europeus cosmopolitas casualmente comparam seu ofício de ministrar aulas numa pequena universidade local a um massacre, e referem a si mesmos como açougueiros. É apropriado que, poucas páginas antes disso, eles desfrutassem de um churrasco:

No quintal em que se fazia o churrasco contemplaram inúmeros buracos fumegantes. Os professores da Universidade de Santa Teresa demonstraram inusitados dotes para os labores do campo 
[...] trataram de desenterrar o churrasco, e um cheiro de carne e terra quente se estendeu pelo quintal na forma de uma fina cortina de fumaça que envolveu a todos como a névoa que precede os assassinatos e que se esfumou de maneira misteriosa, enquanto as mulheres levavam os pratos para a mesa, deixando as roupas e a pele impregnadas do aroma deles. (BOLAÑO, 2010, p.151)

Essa afinidade entre magistério e assassinato não é causal, mas também não é casual. Sua aproximação no quintal permite que o fedor da morte permeie todos os domínios da cultura que antes imaginávamos impermeáveis. A sinestesia do odor de carne penetrando as roupas femininas ilustra esse ponto com brilhantismo.

Como vimos, Bolaño é um dos muitos autores que contemplam o horror e questionam o que se deve fazer a respeito. A questão não se restringe à advocacia; como escritores e artistas visuais, o que é preciso acontecer com a forma? Eis uma pergunta que críticos podem adaptar e adotar conforme suas próprias práticas e métodos e, mais uma vez, independentemente de serem ativistas ou não. A meu ver, uma certa condição transcendental constitui parte importante das abordagens worldlit: nós escrevemos com uma consciência do mundo renovada, como se estivéssemos na presença de companheiros distantes, alguns mais, outros menos, possuidores de um conhecimento mais profundo de outras línguas e tradições. Aqui, argumentei que há valor em revigorar essa consciência se dermos maior atenção ao corporal. Escrever a história da literatura e engajar-se com o mundo não há de ser uma proposição do tipo ou isso/ou aquilo.

\section{Materialismos transculturais}


A narrativização dos cadáveres fornece uma ponte entre a agência da linguagem e a agência da (outra) matéria. A palavra "cadáver", como a palavra "carne", possui uma qualidade quase totêmica: ambas prescrevem diferenças entre o modo com que animais humanos e não humanos se comportam em relação a seus próprios restos. Efeito potente pode surgir da desnaturalização desses termos. Seria insensível referir-se ao cadáver de um ente querido como "cadáver" - imagine "carne"! Esse caso pede que refiramos a um possessivo impossível, o corpo "dela" ou "dele", embora corpos devam ter vida para justificar o nome, e para se ter um corpo é preciso estar vivo. $\mathrm{O}$ abjeto e seus nomes impróprios nos aproximam da humanidade em um sentido não humanista: em vez de enfatizar a nossa excepcionalidade em relação ao resto da natureza, ele sublinha a continuidade. De maneira geral, a World Literature sempre foi excessivamente humanista. Enquanto isso, tendências contemporâneas, como estudos animais, novos materialismos, pós-humanismo etc., são marcadamente pós-antropocêntricas. Chegou a hora de pô-las todas em contato.

The New Human in Literature (2014), de Thomsen, tematiza tópicos pós-humanos de maneira competente - prostética, prolongamento da vida, etc. Em leituras de Woolf, Achebe, Céline, DeLillo e outros, o estudo articula com eloquência o caso de como a literatura pode contribuir para o pensamento crítico sobre inovações biomédicas e, por outro lado, como a ciência moderna pode informar práticas hermenêuticas. A grande questão, porém, da relação entre mundo e linguagem - literatura, portanto - permanece. O mesmo pode ser dito sobre a oportuna proposta de Vilashini Cooppan (2013) de uma história não linear da World Literature, compreendida como uma descrição não hierárquica do fenômeno como fluxo em rede. A minha proposta suplementa, muito mais do que contradiz essa última abordagem, embora o trato dado por Cooppan à morte, inspirada por Kittler, difira do meu. Quando ela observa serem 
todos os livros, livros dos mortos, eu diria - e a diferença, já vimos, não é insignificante - que todos os livros são livros de cadáveres.

Cheah nos alerta sobre a "teleologia do conceito", marca do eurocentrismo hegeliano. Em suas palavras, "enquanto espírito, o conceito se desenvolve ao externalizar-se na esfera da existência objetiva que lhe é alheia" (CHEAH, 2016, p. 58). Segundo um telos espiritualista, a World Literature cumpriria seu objetivo quando o mundo se tornasse legível para si, no nível da abstração, como se o vocábulo "cadáver" pudesse produzir efeito idêntico ao impacto causado pela contemplação de um objeto tão humano. Permitir que o projeto institucional da World Literature não tenha um direcionamento claro, como uma espécie de entusiasmo sem fins, abre as portas para que as ideologias mais prevalentes da atualidade determinem seu rumo. Isso resultaria na imposição de mais acúmulo injustificado de trabalho, mais dispersão da atenção produtiva, mais ecumenismo cegamente excludente, e mais economia de gotejamento baseada em prestígio cultural. Poderíamos, em vez disso, examinar o chão em que pisamos. Meu interesse por narrativas de cadáveres é parte de um projeto maior, o qual venho chamando de "materialismo transcultural": um modo crítico de narrar que corta a divisa natureza-cultura a fim de afetar nossa relação com as coisas e repensar nosso posto na história humana/ nãohumana. A World Literature ainda precisa assimilar o quanto do mundo não é humano; o abjeto, em sua condição de limiar, é um bom ponto de partida.

O desconstrucionismo e o pós-estruturalismo viam cada palavra como um trocadilho em potencial, sua energia dispersiva à espera de um gatilho. Lançando mão de narrativas de cadáveres, tentei aqui fazer algo similar com a World Literature. Permutações são bem-vindas: mundo e literatura, mundo ou literatura, war literature, worm literature - iteratur. 9

9 Nota do tradutor: aqui o autor ludicamente produz permutações fonéticas do termo "World Literature": "war literature" soa parecido, e significa "literatura de guerra"; assim como "worm literature", que significa "literatura de vermes". "Iteratur" ecoa tanto o alemão em Weliteratur quanto a forma passiva indicativa em terceira pessoa do verbo latino iterāđre. 
Errâncias como essas nos aproximam do real muito mais do que reificações o fariam. A literatura latino-americana contemporânea, um campo de estudos fascinante que cada vez mais recebe novos leitores globais por intermédio de traduções cada vez melhores e mais oportunas, dá as provas. Permitamos que as literaturas do mundo teorizem enquanto são teorizadas. Temperemos a pressa de Goethe e sua teleologia do progresso com uma imagem dialética, paradoxal, que Bolaño convoca em diversas ocasiões: "los grandes cementerios a la velocidad de la luz".

\section{Referências}

ADORNO, T. W; Horkheimer, M.. Dialética do Esclarecimento. Tradução de Guido Antonio de Almeida. Rio de Janeiro: Zahar, 2014. E-book.

APTER, Emily. Against World Literature: On the Politics of Untranslatability. Nova York: Verso, 2013.

ASSIS, M. de. Memórias póstumas de Brás Cubas. São Paulo: Ática, 1991 [1881].

BOLAÑO, R. Los detectives salvajes. Barcelona: Anagrama, 1998.

- Noturno no Chile. Tradução de Eduardo Brandão. São Paulo: Companhia das Letras, 2000.

. El gaucho insufrible. Barcelona: Anagrama, 2003.

. Nazi Literature in the Americas. Translation by Chris Andrews. New York: New Directions, 2008a. [1996]

. As putas assassinas. Tradução de Eduardo Brandão. São Paulo: Companhia das Letras, 2008b. [2000]

. 2666. Tradução de Eduardo Brandão. São Paulo: Companhia das Letras, 2010. [2004] 
BORGES, J. L. El Aleph. Buenos Aires: Losada, 1949.

CHEAH, P. What is a World? On Postcolonial Literature as World Literature. Durham: Duke University Press, 2016.

COOPPAN, V. Codes for World Literature: Network Theory and the Field Imaginary. In: KÜPPER, J. (org.). Approaches to World Literature. Berlin: Akademie Verlag, 2013. p. 103-119.

DAMROSCH, David. What is World Literature? Princeton: Princeton University Press, 2003.

. Toward a History of World Literature. New Literary History, 39, p. 481-495, 2008.

. (org). World Literature in Theory. London: Wiley, 2014.

DEPRAZ, N. Leib/Körper/Fleisch. In: CASSIN, Barbara (org.). The Dictionary of Untranslatables. Tradução de Emily Apter, Jacques Lezra e Michael Wood. Princeton: Princeton University Press, 2014. p. 561-564.

DERRIDA, J. Margens da Filosofia. Tradução de Joaquim Costa Torres. São Paulo: Papirus, 1991. . La loi du genre.

D'HAEN, T. The Routledge Concise History of World Literature. London: Routledge, 2012.

ECO, U. The Infinity of Lists: An Illustrated Essay. New York: Rizzoli, 2009.

ECKERMANN, J. P. Gespräche mit Goethe in den letzten Jahren seines Lebens. Frankfurt: Insel Verlag, 1981. Disponível em: http://gutenberg. spiegel.de/buch/-1912/80 Acesso em: 10 dez. 2015.

ELTIT, D. Impuesto a la carne. Santiago: Planeta, 2010.

FISK, G. 'Against World Literature': The Debate in Retrospect. The American Reader, [s.l.], 9 de abril de 2014. Disponível em: https://theamericanreader. 
com/against-world-literature-the-debate-in-retrospect/ Acesso em: 10 dez. 2015.

GRAFF, G. Taking Cover in Coverage. Profession 86, p. 41-45. Modern Language Association of America, 1986.

HALFÓN, E. “Han vuelto las aves.” In: . Signor Hoffman. Barcelona: Libros del Asteroide, 2015.

HOHENDAHL, P. U. A Precarious Balance: Adorno and German Classicism. In: New Literary History, vol. 42, no. 1 (WINTER 2011), pp. 31-52. The Johns Hopkins University Press.

HOYOS, H. Beyond Bolaño: The Global Latin American Novel. New York: Columbia, 2015.

KANT, I. Crítica da faculdade de julgar. Tradução de Fernando Costa Mattos. Petrópolis: Vozes, 2016.

KRISTEVA, J. Os poderes do horror. Tradução parcial de Allan Sena da obra de . Pouvoirs de l'horreur: Essai sur l'abjection. Paris: Éditions du Seuil, 1980. Tradução publicada na internet em 2021 e disponível em: https://www.academia.edu/18298036/Poderes do Horror de Julia Kristeva Cap\%C3\%ADtulo 1. Acesso em: 18 jun. de 2018.

ROSA, R. R. El material humano. Barcelona: Anagrama, 2009.

ROSERO, E. Los ejércitos. Bogotá: Tusquets, 2007.

SCHMITT, C. Roman Catholicism and Political Form. Tradução de G.L. Ulmen. Westport: Greenwood Press, 1996 [1923].

SMITH, P. Hecatomb: A Poem. Ilustrada por José Antonio Suárez Londoño. Medellín: SML ediciones, 2013.

THOMSEN, M. R. Mapping World Literature. New York: Continuum, 2008. . The New Human in Literature. Posthuman Visions of Changes in 
Body, Mind and Society after 1900. London: Bloomsbury, 2014.

ŽIŽEK, S. The Indivisible Remainder: An Essay On Schelling And Related Matters. Londres: Verso, 1996.

Corpse narratives and the teleology of world literary history

Abstract: The present essay proposes an orientation towards the corpse as a viable telos for the present-day revival of World Literature as critical paradigm. The argument has three parts. First, it characterizes two central tenets of the existing paradigm: a profession of dynamism for its own sake and an implicit lack of finality. Drawing on Kristeva and on examples from contemporary Latin American fiction, especially Roberto Bolaño's 2666, the article then introduces corpse narratives that embrace the abject and reorient critical practice towards materiality. Finally, the conclusions propose a modest agenda for a different "worldliteraturism" that valorizes abject materiality over high-minded idealism.

Keywords: Necropolitics. New materialisms. World Literature. Contemporary Latin American literature. Corpses.

Recebido em: 13/09/2021

Aceito em: 17/09/2021 